\title{
IMMUNOHISTOGHEMICAL STUDY OF URIDYLTRANSFERASE IN THE BOVINE LIVER
}

\author{
Noboru YAMAMOTO AND KenjIRo YASUDA \\ Department of Anatomy, School of Medicine, Kitasato University, \\ Sagamihara, Kanagawa 228
}

Received for publication November 9, 1972

\begin{abstract}
The distribution of galactose 1-phosphate uridyltransferase in the bovine liver was investigated by aid of the immunohistochemical method.

The enzyme used in this study was found to contain small amount of contamination by the Ouchterlony gel-diffusion test. The enzyme is present in the liver cells surrounding the central vein. The concentration of the enzyme decreases towards the middle and peripheral regions of a lobule. In the cytoplasm of each liver cell, the enzyme is distributed in the coarse granular as well as in the diffuse pattern. In the electron microscopic study the enzyme is recognized in the amorphous part of the cytoplasm, being not associated with any organelles. In the occasional cells, the enzyme is localized only the amorphoüs part of the cytoplasm. It is never found in the nucleus. Furthermore, the specific staining is not seen in the endothelial cells of the sinusoid, stellate cell of Kuppfer, the cells of the wall of the interlobular bile duct and in the endothelial cells of the interlobular blood vessels.
\end{abstract}

The conversion of galactose to glucose in biological systems has been shown by Leloir (1951) and Kalcker (1957) to be intimately linked with the metabolism of uridine nucleotides. In order to enter the glucose metabolism, $\alpha$-D-galactose is first converted by galactokinase (ATP: D-galactose 1-phosphotransferase EC 2.7.1.6) to $\alpha$-D-galactose 1-phosphate (Gal-1-P). The subsequent conversion of Gal-1-P to glucose 1-phosphate (Glc-1-P) involves the following reactions:

$$
\begin{aligned}
& \text { Gal-1-P }+ \text { UDP-Glc } \rightleftarrows \text { Glc-1-P }+ \text { UDP-Gal } \\
& \text { UDP-Gal } \rightleftarrows \text { UDP-Glc } \\
& \text { UDP-Glc }+\mathrm{PPi} \rightleftarrows \text { Glc-1-P }+ \text { UTP }
\end{aligned}
$$

The enzymes catalyzing these reactions are Gal-1-P uridyltransferase (EC 2.7.7.12), UDP glucose 4-epimerase (EG 5.1.3.2), and UDPglucose pyrophosphorylase (EC 2.7.7.9), respectively.

These enzymes have been shown to be present in the liver, mammary gland and in the erythrocyte (Kurahashi et al., 1958). The Gal-1-P uridyltransferase has been shown to be absent in the tissues of patients with galactosemia (Kalcker, 1959). The deficiency of transferase causes an impaired utilization of ingested galactose, resulting in the accumulation of Gal-1-P in tissues (Schwarz et al., 1953).

The authors in this paper attempted to localize Gal-1-P uridyltransferase in the bovine liver using the immunohistochemical method, to elucidate the sites of the metabolism of galactoase in the cell. 


\section{MATERIALS AND METHODS}

Antigen: Crystalline uridyltransferase (UDPglucose: $\alpha$-D-galactose 1-phosphate uridyltransferase EG 2.7.7.12) from calf liver was purchased from Boehringer Mannheim GmbH, Mannheim, Germany and used as antigen in this study. According to the description in the assay data sheet offered from the company, the contaminants in relation to the specific activity of uridyltransferase were as follows: 6-PGDH, phosphodiesterase each $<0.01 \%$, NADPH-oxidase $<0.1 \%$, glucose dehydrogenase $<1 \%$ and UDPG-pyrophosphorylase $<5 \%$, respectively.

Preparation of antibody: $10 \mathrm{mg}$ of the enzyme preparation dissolved in the phosphate buffered saline was mixed with an equal volume of Freund's complete adjuvant and injected subcutaneously in the foot pads of rabbits. Four weeks after the initial injection, $5 \mathrm{mg}$ of the enzyme was administrated intravenously for the booster injection. Seven days after the final injection, anti-uridyltransferase serum was harvested from the animals. The antisera were pooled, and the antibody titer was measured roughly by two dimensional gel-diffusion.

Preparation of $\gamma$-globulin: The crude $\gamma$-globulin was obtained by the precipitation with ammonium sulfate at the concentration of $50 \%$ saturation. The precipitate was collected, dissolved in the minimum volume of water and desalted by use of a sephadex G-25 column. The desalted solution was applied to a DEAE-cellulose column which preequilibrated with $0.005 \mathrm{M}$ phosphate buffer, $\mathrm{pH}$ 8.0. $\quad \gamma$-Globulin was obtained in the fraction which passed through the column by the elution with $0.005 \mathrm{M}$ phosphate buffer, $\mathrm{pH}$ 8.0.

Conjugation with horse raddish peroxidase or mercury orange: The purified antiuridyltransferase $\gamma$-globulin was conjugated with horse raddish peroxidase (HPO) by the methods of Nakane et al. (1966), and Avrameas (1969). The HPO-labeled $\gamma$-globulin was purified by use of a molecular seive chromatography on sephadex G-200 column as descrived eleswhere (Yamamoto et al., 1972).

The mercury orange (MO)-labeled antibody was prepared by the method of Yasuda (1972). $\quad \gamma$-Globulin was thiolated by aid of $\mathrm{N}$-acetyl-homocystein thiolactone. Mercury orange was added to the thiolated $\gamma$-globulin at the ratio of $1 / 60$ of the protein amount. The unconjugated mercury orange was removed by the chromatography on sephadex G-25 column.

Liver tissue and staining: Normal bovine liver for this study was obtained at the slaughter house. The tissue was cut in pieces of about $3 \mathrm{~mm}$ in diameter and was fixed with the mixture of the equal volume of $4 \%$ paraformaldehyde and $2 \%$ glutaraldehyde, prepared in $0.1 \mathrm{M}$ phosphate buffer, $\mathrm{pH}$ 7.5. After the fixation for two hours, the block was washed in the phosphate buffered saline for overnight.

For the light microscopic study, the block was dehydrated with serial of ethanols at $-20^{\circ} \mathrm{C}$ and embedded in paraffin as a regular course for the preparation of the light microscopic specimens. 5-10 $\mu$ thick sections were exposed to the HPO-conjugated antibody solution for 2 hours at the room temperature and rinsed well with phosphate buffered saline. The sections were stained in the darkness for $10 \mathrm{~min}$ in the $\mathrm{DAB}$ solution which is composed of $5 \mathrm{mg} / 10 \mathrm{ml} \mathrm{DAB}$ (3,3'-diaminobenzidine tetrahydrochloride, purchased from Dohzine Chemical Co. Ltd., Kumamoto, Japan), $0.001 \% \mathrm{H}_{2} \mathrm{O}_{2}$ and $0.1 \mathrm{M}$ Tris-HCl buffer, pH 7.4. 


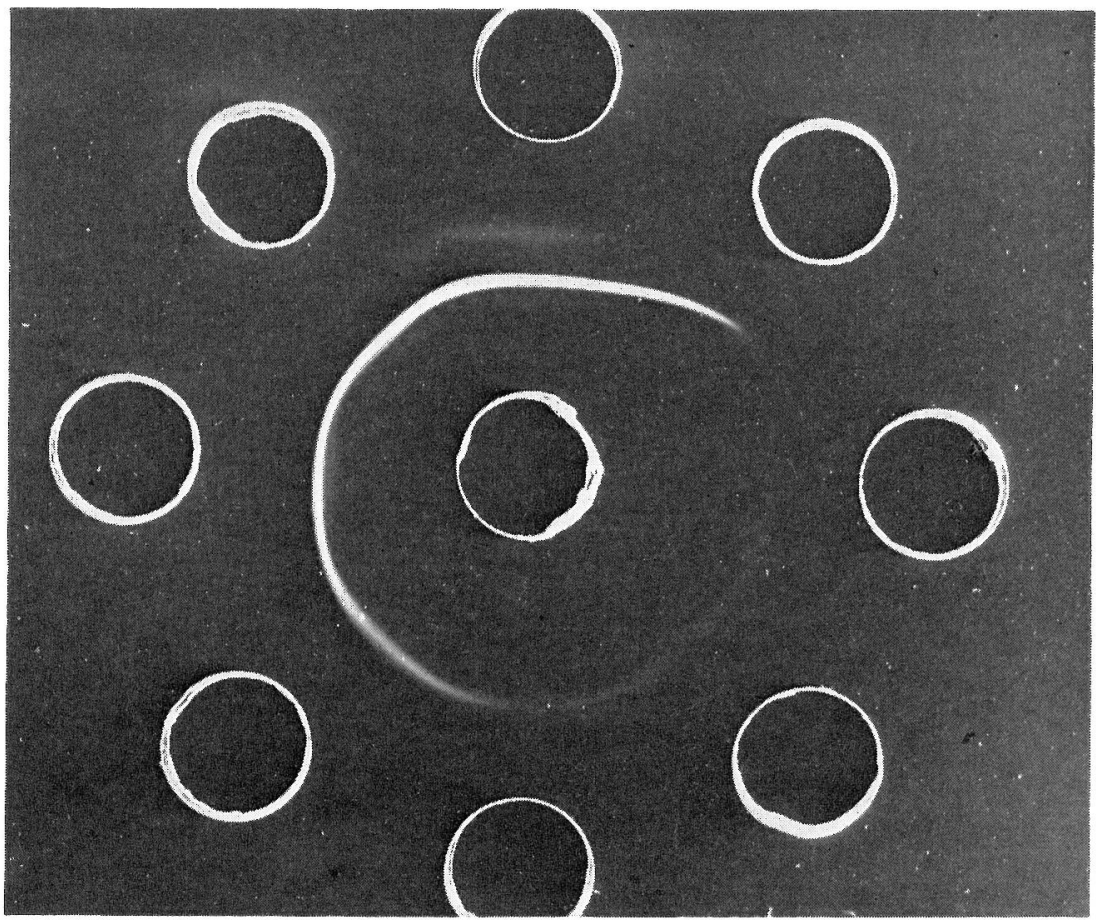

FIG. 1. Precipitin reaction on the agar plate (Ouchterlony technique).

The center well containes anti-uridyltransferase serum, surrounding wells are filled with different dilutions of the antigen, containing $20 \mathrm{mg} / \mathrm{ml}, 10 \mathrm{mg} / \mathrm{ml}, 5 \mathrm{mg} / \mathrm{ml}, 2.5 \mathrm{mg} / \mathrm{ml}, 1 \mathrm{mg} / \mathrm{ml}$, $0.5 \mathrm{mg} / \mathrm{ml}, 0.25 \mathrm{mg} / \mathrm{ml}$ and $0.1 \mathrm{mg} / \mathrm{ml}$ respectively counterclockwise, beginning from the top well. One thick band and another faint line are recognized, representing the presence of two antigen-antibody systems.

For the electron microscopic study, $20-40 \mu$ thick slices were prepared by use of tissue sectioner, TG-2, Sorvall. Some of these slices were immersed in the HPO-conjugated antibody solution for 2 hours at room temperature and rinsed well in the phosphate buffered saline. Then the slices were stained with a $\mathrm{DAB}$ solution at the same procedure as described above, except for the extention of the reaction time to 30 minutes.

The other slices were immersed in the MO-labeled antibody for 2 hours at room temperature and rinsed well in the phosphate buffered saline. Then the slices were impregnated in $1 \%$ gold chloride solution for the enhancement of the contrast under the electron microscope (Yasuda, 1972).

Post-fixation with osmium tetroxide, dehydration in sequential changes of cold ethanols and embedding with epoxy resin were carried out as a regular course for the preparation of the electron microscopic specimens. Ultra-thin sections were obtained by use of Porter Blum MT-1 ultramicrotome furnished with glass knives. The specimens were examined with HS-8 electron microscope operated at $50 \mathrm{KV}$. 


\section{RESULTS}

The enzyme was mainly encountered in the liver cells surrounding the central vein (Figs. 2,3). The number of the cells containing the enzyme decreases towards the middle and peripheral regions of a lobule. In the cytoplasm of the liver cells which contain Gal-1-P uridyltransferase, the enzyme was observed rather in the granular than the diffuse pattern under the light microscope. Electron microscopic observation, however, reveals that the cytoplasm of the enzyme-containing liver cell was stained diffusely in the amorphous part by the staining with DAB solution (Figs. 4, 5). Using MO-labeled antibody, however, the enzyme was located in a definite part of the amorphous cytoplasm (Figs. 6, 7). These definite parts of the cytoplasm seemed to correspond to the granular configuration in the light microscopic observation.

The glycogen area appeared to be entirely free of the enzyme. Furthermore, the enzyme was located in a definite liver cells even in the surroundings of the central vein, leaving the adjacent cell unstained.

This enzyme was not present in the nucleus. Furthermore, the specific staining was observed neither in the endothelial cells of sinusoid nor in the stellate cells of Kuppfer. The positive deposits were observed in the lumen of the interlobular bile duct, interlobular artery and in that of interlobular vein by use of the MOlabeled antibody (Figs. 6, 7). But those deposits were not seen in the tissues which were exposed to the HPO-labeled antibody (Figs. 4, 5). Those deposits which

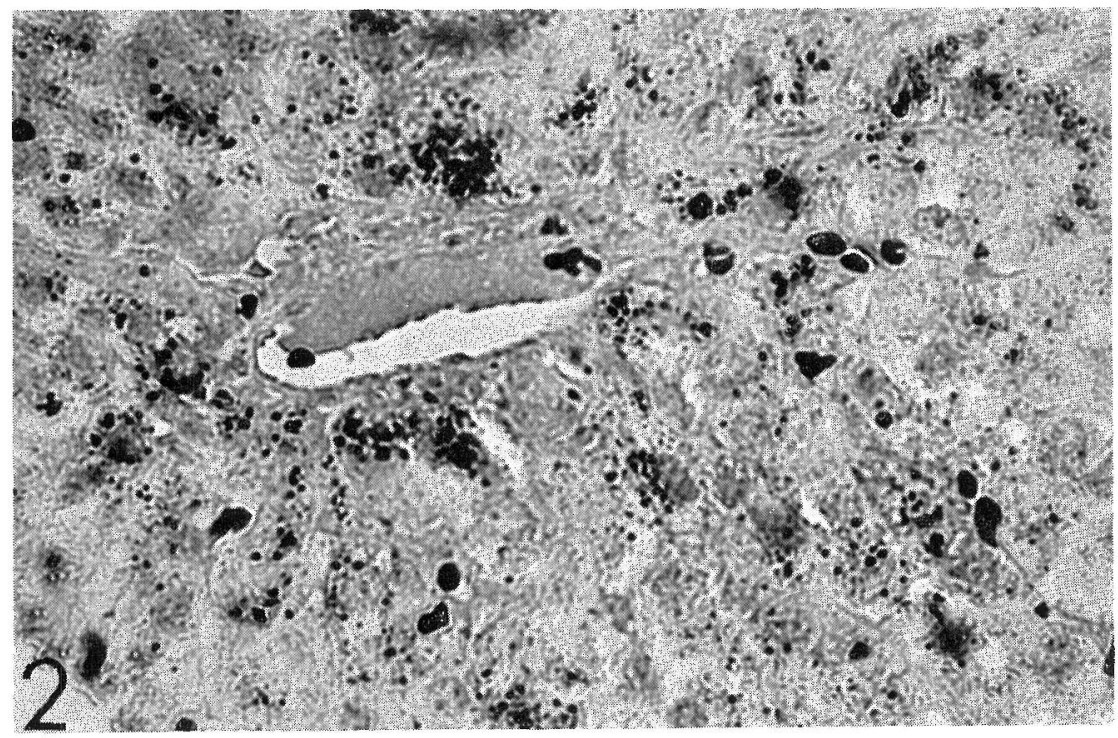

FIG. 2. The distribution of uridyltransferase in the bovine liver.

The reaction products are present in the small granular pattern, in the liver cells surrounding the central vein. The deposits decrease towards the middle and peripheral regions of a lobule. The large granules in this figure are erythrocyte and the deposits are attributed to the endogenous reaction. $\times 200$. 


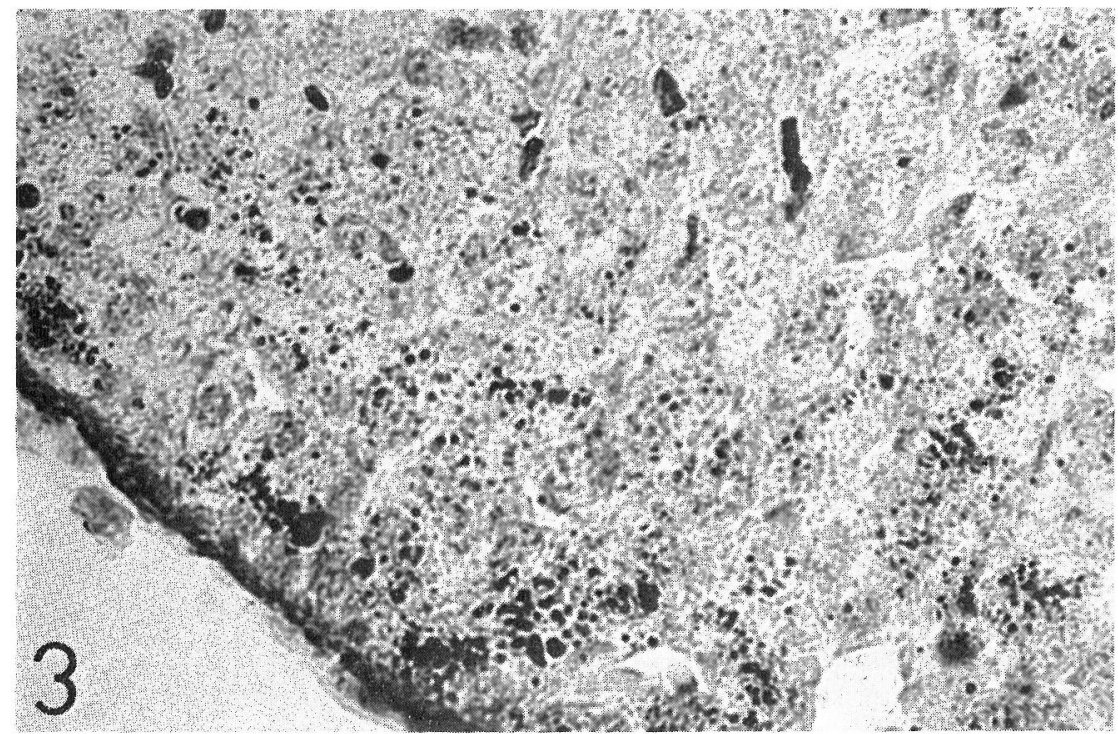

FIG. 3. High magification of the feature around the central vein. $\times 400$.

were seen only by use of the MO-labeled antibody may possibly be of non-specific nature.

In both sinusoid and central vein, there were numerous erythrocytes which demonstrate positive reaction to $\mathrm{DAB}$ (Figs. 2, 3). This reaction was not a specific immunological reaction but was attributable to the endogenous hemoglobin.

\section{DISGUSSION}

It has been well known that the glycogen was accumulated in the peripheral area of a liver lobule and decreased in amount in the area surrounding the central vein. By the histochemical technique, it has been shown that UDPG-glycogen transferase (EG 2.4.1.11) and branching enzyme (EC 2.4.1.18) were located in the peripheral liver cells more than those surrounding the central vein (Takeuchi, 1964). On the other hand, the amylophosphorylase (EG 2.4.1.1) located mainly in the cells surrounding the central vein.

In order to participate in the glucose metabolic pathway, $\alpha$-D-galactose is first converted by galactokinase to $\alpha$-D-galactose 1 -phosphate. The sequential conversion of Gal-1-P to glucose 1-phosphate involves the following reactions:

Figs. 4, 5. Electron micrograph, showing the location of the enzyme demonstrated by HPOlabeled antibody technique.

The enzyme is found in the definite liver cell. Even the cells which are adjacent to the enzyme-containing cell are not frequently contained the enzyme. The cytoplasm of the enzyme-containing liver cell was stained diflusely in the amorphous part by the staining with DAB solution. The electron opaque deposit are not always associated with the definite cell organelles. $\times 8,700$. 

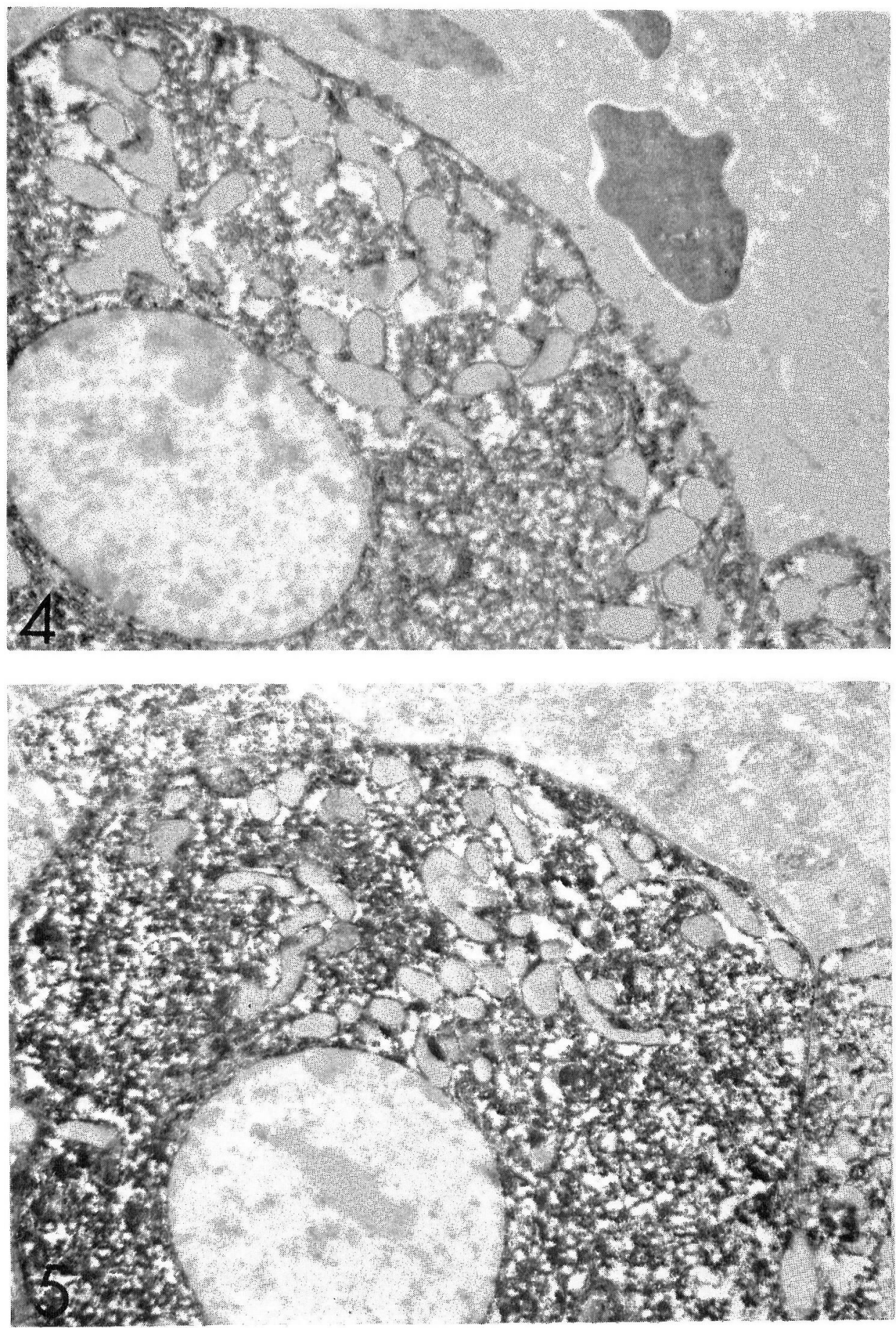


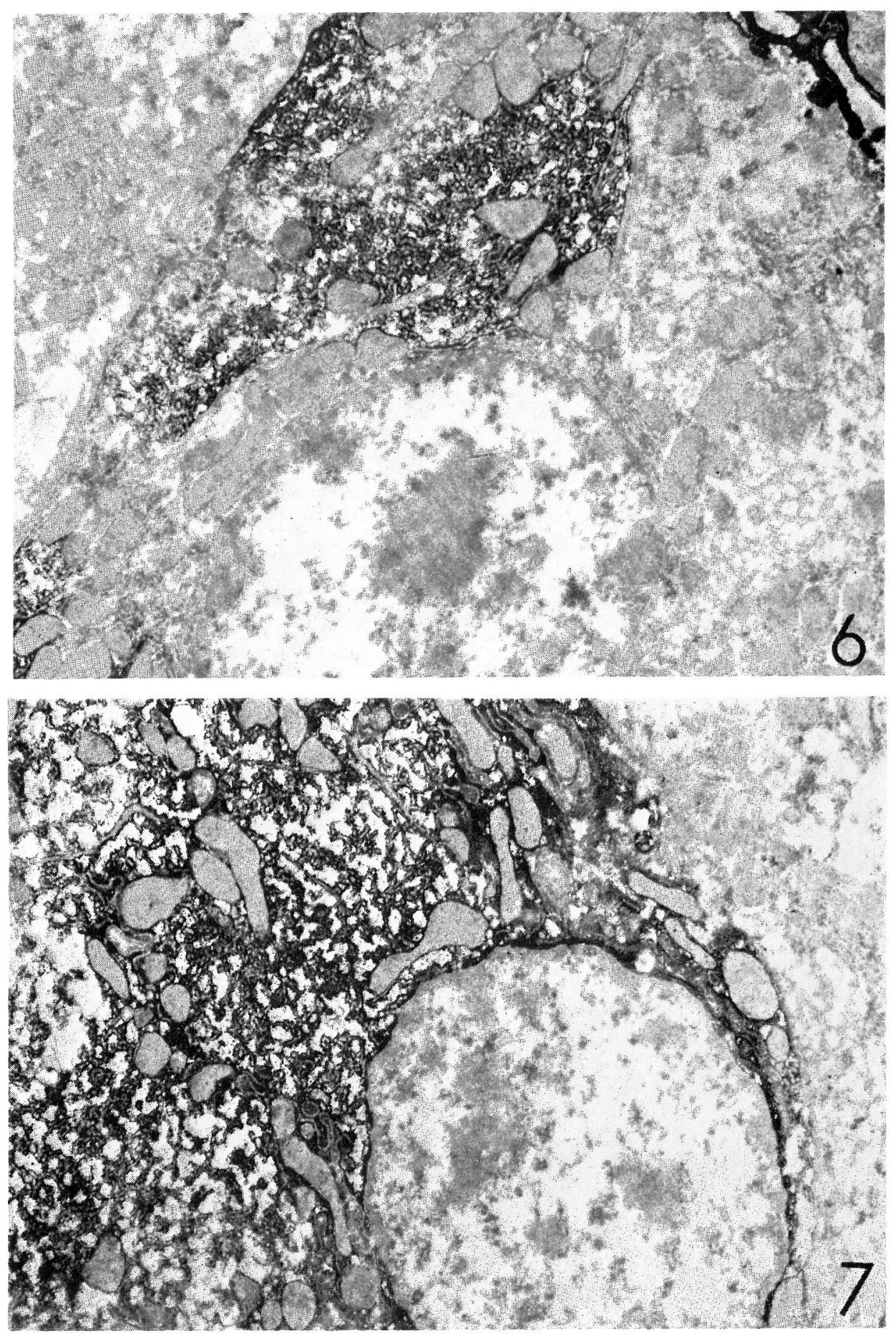




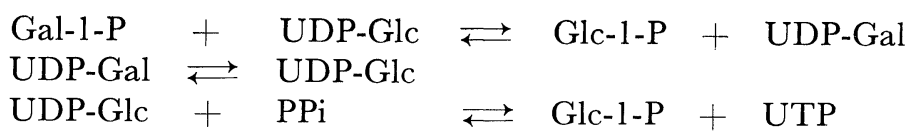

Galactose 1-phosphate uridyltransferase catalyzes the first reaction.

In our morphorogical study using immunohistochemical method, the enzyme was found in the definite cells surrounding the central vein. This finding seems to be inconsistent with other reports concerning the distribution of UDPG-glycogen transferase and branching enzyme (Takeuchi, 1964), if the enzyme catalyzes the glycogen synthesis, though the location of the enzyme did not coincide with that of the glycogen area. However, glucose 1-phosphate which produce by the sequential reactions described above may be rapidly changed to glucose 1,6-diphosphate by the catalysis of glucose 1-phosphate phosphodimutase (EG 2.7.1.41). The further study on the location of the other enzymes, such as glucose 1-P phosphodimutase, UDPglucose-4-epimerase and UDPglucose pyrophosphorylase, may contribute to the elucidation of the relationship between glycogen metabolism and the sites of the enzyme concerning the proper metabolism.

It was interesting and also unexpected that, only the definite cells contain the enzyme, even at the center of the lobule. These have been not so much papers reporting the functional specialization of the definite cells in the liver, except that the report of Hamashima et al. (1964) which dealt with the location of albumincontaining cells and fibrinogen-containing cells in the human liver. According to them, the former cells tend to locate in the surrounding the central vein, while the latter distribute themselves partly in the periphery of a lobule in group as well as in every region in the scattered pattern. The distribution pattern of the enzyme-containing cells in this study is quite similar to that of the albumincontaining cells, though this coincidence does not mean that the enzyme containing cells are identical to the albumin-containing cells. Since the glycogen metabolism is one of the most important aspect of the liver function, it is more likely that the presence of the definite enzyme-containing cells does not reflect the functional specialization of a certain cell group, but suggest the heterogenity of the functional phase of the liver cells.

\section{REFERENCES}

1. Avrameas, S.: Coupling of enzymes to proteins with glutaraldehyde. Use of the conjugates for the detection of antigens and antibodies. Immunochemistry 6; 43, 1969.

2. Hamashima, Y., Harter, J. G. and Coons, A. H.: The localization of albumin and fibrinogen in human liver cells. J. Cell Biol. 20; 271, 1964.

3. Kalcker, H. M.: Biochemical mutations in man and microorganisms. Science 125; 105, 1957.

4. Kalcker, H. M.: Biochemistry of human genetics. Ciba Found. Symp., Little Brown and Co., Boston, 1959. p. 347.

5. Kurahashi, K. and Anderson, E. P.: Galactose 1-phosphate uridyl transferase, its purification

Figs. 6, 7. Electron microscopic observation by using MO-labeled antibody.

The enzyme was located in a definite part of the amorphous cytoplasm. The definite parts of the cytoplasm seemed to correspond to the granular configuration in the light microscopic observation. $\times 8,700$. 
and application. Biochim. Biophys. Acta 29; 498, 1958.

6. Leloir, L. F.: Phosphorus metabolism., Vol. 1, The Hopkins Press, Baltimore, 1951.

7. Nakane, P. K. and Pierce, G. B.: Enzyme-labeled antibodies for light and electron microscopic localization of tissue antigens. J. Cell Biol. 33; 307, 1967.

8. Schwarz, V. and Goldberg, L.: Galactose 1-phosphate in galactose cataract. Biochim. Biophys. Acta 18; 310, 1955.

9. Takeuchi, T.: "Histochemistry-Liver, Structure, Function and Clinics", in Japanese, Igakushoin, 1964, p. 60.

10. Yasuda, K.: Development of a new technique for immunohistochemistry, in "Application of Cytochemistry to the Studies of cell function" US-Japan Seminar Program, 1972, p. 41.

11. Yamamoto, N. and Yasuda, K.: The purification of enzyme-labeled antibody on sephadex G-200 column chromatography. Kitasatoigaku, in Japanese, 2; 194, 1972. 